\title{
A Dádiva do Torrent ${ }^{1}$
}

\section{Gabriel Ferreirinho}

Universidade Federal Fluminense - Brasil - gabrielferreirinho@gmail.com

\begin{abstract}
Sumário
O presente trabalho busca discorrer sobre as

modo de compartilhamento online e a noção circulações de bens a partir do download de torrents sob uma perspectiva da troca pela dádiva. Inicialmente são apresentadas algumas noções de dádiva principalmente a partir das discussões do trabalho de Mauss (2003) em interlocução com outros autores que trabalharam o conceito mais recentemente. Em um segundo momento são apresentadas possibilidades de perceber a dádiva na internet $\mathrm{e}$ o funcionamento do torrent, para, em seguida, realizar a discussão da relação entre esse de dádiva, baseada numa revisão bibliográfica de pesquisas etnográficas sobre o compartilhamento peer-to-peer. É possível identificar a tripla obrigação: dar, receber e retribuir nos compartilhamentos de informação e conteúdo através do torrent por categorias que se assemelham às categorias tradicionais, mas também é necessário reconfigurar o contexto para que dialogue com o cenário contemporâneo que inclui os meios digitais e suas especificidades de partilha.
\end{abstract}

Palavras-chave: Dádiva, torrent, tripla obrigação, peer-to-peer.

\section{The Gift of Torrent}

\begin{abstract}
The present work seeks to discuss the circulasharing and the notion of gift, based on a bibtions of goods from the download of torrents from a perspective of the exchange for the gift. Initially some notions of gift are presented mainly from the discussions of the work of Mauss (2003) in interlocution with other authors who worked the concept more recently. In a second moment, possibilities of perceiving the gift on the internet and the operation of the torrent are presented, and then the discussion liographical review of ethnographic research on peer-to-peer sharing. It is possible to identify the threefold obligation to give, receive, and retribute information and content shares through torrent by categories that resemble traditional categories, but it is also necessary to reconfigure the context to dialogue with the contemporary setting that includes digital media and their specificities of sharing.
\end{abstract} of the relationship between this mode of online

Keywords: Gift, torrent, threefold obligation, peer-to-peer.

1 O presente trabalho foi realizado com apoio da Coordenação de Aperfeiçoamento de Pessoal de Nível Superior - Brasil (CAPES) - Código de Financiamento 001. 


\section{INTRODUÇÃ̃O}

Marcel Mauss foi um sociólogo e antropólogo francês que ficou muito conhecido por seu trabalho no qual observou grupos com formas de lidar com a troca, que escapavam dos sentidos hegemônicos ocidentais capitalistas, um sistema de prestação o qual denominou dádiva. Enxergou um fato social total, como era pensada a sociologia da época, por perceber como a lógica por trás dessas trocas exercia influência em toda a organização social (política, religiosas, econômicas, "jurídica”, familiar) (Giesler, 2006; Mauss, 2003). Para Caillé (1998), estudioso da obra de Mauss, um dos maiores ganhos da reflexão do antropólogo foi a complexidade analítica colocada através da tripla obrigação: dar, receber e retribuir, somada à percepção de que na dádiva encontra-se ao mesmo tempo liberdade e obrigação e interesse e desinteresse (Mauss, 2003).

Já preliminarmente, também sob as indicações de Caillé (1998), é imprescindível conceber de que o objetivo não se situa no encontro do que seja uma essência fundamental da dádiva, mas sim, em articular suas propriedades e sua história para o encontro do momento contemporâneo no que se refere às práticas na internet. Além disso, Giesler (2006) indica como a investigação de práticas na internet a partir da perspectiva da dádiva, reforça o sentido de reconfigurarmos esse conceito no espaço e tempo, para que não fique preso a ideia de que só pode ser encontrado em sociedades "tribais"; apesar de o autor acreditar na possibilidade de encontrar a dádiva em sua forma "pura", será descartado o debate da pureza do conceito e me aterei a operar suas características a partir das práticas de download por torrent.

Nessa direção, um ponto importante é entender que a economia da troca-dádiva muitas vezes se mostrou distante de uma inserção no modelo de uma economia tida como natural, que prevê o utilitarismo (Mauss, 2003); e até hoje se faz necessário pensar as relações das trocas entre pessoas não somente centrado nessa categoria da lógica utilitária do modelo contratual (Apgaua, 2004). Apesar de há muito tempo as pesquisas sobre consumidores terem tangenciado a questão da dádiva, principalmente através da ideia de trocas de presentes, Giesler (2003) é expressivo em sua crítica ao fato do tema ter sido tratado sempre de maneira dicotômica, envolvendo apenas a relação entre dar e receber, além do foco constante entre dois sujeitos; e que os mesmos operadores analíticos que foram utilizados para pensar as tribos poderiam ser acionados ao pensarmos as relações de dádiva contemporânea, caso contrário nos fecharíamos em uma lógica evolucionista. 
Ao mesmo tempo, a compreensão atual de pirataria também estaria equivocada; hoje os sentidos que atribuímos às práticas de compartilhamentos de arquivos pela internet caem em dois caminhos, ou criminalidade ou mercados não atingidos; enquanto o primeiro oculta as relações e complexidades que se configuram a partir desses usos, o segundo tenta fixar as possibilidades de sentido em uma lógica capitalista de trocas de mercadorias (Caraway, 2012). Isso não quer dizer que devamos pensar a internet como um espaço separado do que seria colocado como o "real", e também não acreditar que a transferência de arquivos a partir das práticas de peer-to-peer estão fora da lógica legal de direito autoral, mesmo em grupos de compartilhamento por torrent que são fechados para membros (Frostgård, 2012).

É significativo deixar claro que não é proposta uma crítica ao consumo, como trabalhado por Miller (2007), em que a materialidade é vista como ameaça, mas o contrário, trabalhar como a circulação de bens está associada a valores espirituais e morais; e que a produção e circulação de bens também são um processo cognitivo, em que não só materialidades são desenvolvidas, mas tem seu aspecto cultural (Kopytoff, 2008). Além disso, podem emergir da reflexão formas de consumo moderno, através das circulações de bens, que extrapolam nossa ideologia de associação direta ao individualismo (Campbell, 2006), algo a se ter atenção, já que muitas críticas feitas à noção de dádiva partem dos pressupostos de interesses e satisfações individuais, e se fixam extremamente sobre eles.

Necessitamos do exercício de um pensamento complexo, já que, como demonstardo por Giesler (2006), um olhar simplista acerca das práticas que englobam a dádiva em que se forçam mecanismos bilaterais, individuais ou puramente econômicos não são o bastante para enxergar todas as potências desse sistema de prestações. Somado a isso, uma questão mais contemporânea em relação ao estudo da dádiva em trocas de arquivos por torrent se faz presente durante a argumentação; serão as concepções de solidariedade e comunidade necessárias para identificar um sistema de dádivas contemporâneo?

Para apresentar as considerações contemporâneas em relação às possibilidades de dádiva na internet pelo download de torrent, irei apresentar algumas características importantes da dádiva, principalmente sobre o trabalho de Mauss (2003); em seguida, alguns dos elementos e funcionamentos principais dos compartilhamentos de arquivo peer-to-peer através de torrent, para então discutir as aproximações e distanciamentos entre os dois tópicos, assim como as discussões dos trabalhos que se focaram em temas semelhantes. 


\section{A Dádiva do Torrent}

\section{SOBRE A DÁDIVA}

Em Ensaio sobre Dádiva, Marcel Mauss (2003) analisa um sistema de prestações, a dádiva, o qual observou em diversas sociedades americanas, na Polinésia e Melanésia que se configura em três obrigações complementares e interdependentes: dar; receber e retribuir; além de imersa em um duplo paradoxo, já que é ao mesmo tempo livre e obrigatória e interessada e desinteressada. Nessas relações, vida material e moral se interpelam, pois existe uma ligação espiritual entre os bens e os seres humanos aos quais estão ligados, trocam-se matérias espirituais e não há uma concepção de distinção completa entre seres, coisas e espiritualidade, elas estão imbricadas umas as outras.

Antes de tudo, é necessário se despir de algumas concepções contemporâneas do nosso sistema de prestações; ao pensar a dádiva, Mauss (2003) indica que não são indivíduos que estão envolvidos nas obrigações, trocas e contratos, mas coletividades que se expressam como clãs, tribos, famílias, por exemplo, mesmo que às vezes exista a moderação de um chefe. Além disso, não são "trocados"2 apenas objetos ou riquezas:

São, antes de tudo, amabilidades, banquetes, ritos, serviços militares, mulheres dos quais o mercado é apenas um dos momentos, e nos quais a circulação de riquezas não é senão um dos termos de um contrato bem mais geral e bem mais permanente (Mauss, 2003, p. 191).

Diferente da situação do ocidente contemporâneo, que em geral deposita na capacidade da venda de algo o caráter de um "bem", e enxerga muitas vezes nas coisas que não possuem a característica de ser vendidas uma cisão com o que é mundano e comum, como se possuísse um diferencial intrínseco (Kopytoff, 2008).

$\mathrm{Na}$ teoria do direito e da religião maori, os artigos (taonga) estão diretamente conectados às pessoas, aos agrupamentos coletivos, ao solo, e são percebidos como um propagador de suas energias. Mauss identificará como mana essa matéria espiritual que só alcança sua potência através da reciprocidade das dádivas, na movimentação dos bens materiais ou simbólicos; é ligada ao doador do artigo, fazendo com que quando se dá algo, esteja também dando parte de si e, assim, quem recebe está na

2 Apesar de Mauss utilizar o termo "troca" (2003, p. 191), chama-se a atenção para não significarmos a palavra a partir de nossos sentidos contemporâneos, que tem relação ao nosso sistema hegemônico de prestação. 
obrigação de retribuir (Sabourin, 2008). Outra possibilidade de observar esse poder espiritual ainda na cultura maori é o hau, palavra usada para significar o espírito das coisas vivas e materiais, ou seja, permanece a ideia de que mesmo ao se separar de um artigo, dando-o para alguém, ainda permanece nesse artigo (taonga) parte sua e do hau de sua floresta, território, solo, fazendo com que "doador" e "donatário" criem um vínculo de almas pelas coisas e, inclusive, que exista uma relação de poder entre aquele que deu sobre o que recebeu. Nesse sentido, a lógica ao continuar as movimentações da dádiva pressupõe "que seja preciso retribuir a outrem o que na realidade é parcela de sua natureza e substância" (Mauss, 2003, p. 200). É importante chamar atenção para a reflexão de Sabourin (2008) na qual reposiciona o mana e o hau não apenas como um valor intrínseco ao doador, mas que, na verdade, é um valor produzido a partir da movimentação dos bens, logo, a partir da reciprocidade da dádiva.

Na Polinésia e Melanésia, observou um tipo agonístico ${ }^{3}$ de prestações totais, nos quais a dádiva está também relacionada a um principio de rivalidade, uma vez que existe uma hierarquia implícita ao ato de dar, ele indica uma autoridade, ganha força o grupo que presenteia o outro com melhores bens, e fortalece uma relação de poder até que se seja retribuído; o que ocorre num movimento pendular, já que se retribui também pelo sentimento de compromisso com o que foi recebido; ao mesmo tempo em que se recusar a receber é também uma ofensa que pode gerar, inclusive, guerras.

Percebeu esse mesmo modo agonístico no noroeste americano, no qual observou não haver escambo, mesmo a partir das interações com os europeus, por apontar que todas as transações são realizadas, como na Melanésia, através de um constante dar e receber. Nessas sociedades, existe uma forte correlação entre a dádiva e uma concepção de honra, um chefe só manterá sua autoridade em relação à tribo, aldeia ou família se constantemente distribuir bens, demonstrando que é favorecido pelos espíritos e fortuna, "que é possuído por ela e a possui"4; assim colocando os outros em uma posição menor à sua própria; pois a mistura entre alma, seres e coisas prevê que perder o prestigio seja como perder a própria alma. Nessas sociedades as pessoas costumam dar constantemente, pois é o ato fundamental de reconhecimento; mesmo fora de solenidades e reuniões, há sempre presente a obrigação de convidar os amigos, oferecer-lhes os ganhos, caças, colheitas (que também vêm dos deuses e totens)

3 "Propomos reservar o nome de potlatch a esse gênero de instituição que se poderia, com menos perigo e mais precisão, mas também mais longamente, chamar: prestações totais de tipo agonístico" (Mauss, 2003, p. 192, grifos do autor).

4 (Mauss, 2003, p. 253). 


\section{A Dádiva do Torrent}

e retribuir tudo o que foi recebido de todos que já deram. E é principalmente a partir desse olhar sobre os povos melanésios, polinésios e americanos que vai conceber o regime da dádiva:

A vida material e moral, a troca, nele funcionam de uma forma desinteressada e obrigatória ao mesmo tempo. Ademais, essa obrigação se exprime de maneira mítica, imaginária ou, se quiserem, simbólica e coletiva: ela assume o aspecto do interesse ligado às coisas trocadas: estas jamais se separam completamente de quem as troca; a comunhão e a aliança que elas estabelecem são relativamente indissolúveis (Mauss, 2003, p. 232).

Além desses três exemplos, ao pensar os pigmeus a partir do trabalho de Alfred Radcliffe-Brown, percebe que as trocas de presente não são comparáveis às finalidades do comércio e troca nas sociedades contemporâneas europeias, já que antes de tudo são de carga moral, com o objetivo de formar alianças e amizades que, caso não se findassem, fariam com que a ação não tivesse efeito; numa relação que muitas vezes mistura pessoas e sentimentos. Ainda assim, existia um teor de rivalidade para expressar quem seria capaz de dar mais bens de maior valor e, apesar de serem considerados presentes, as pessoas tinham a expectativa de receber algo de mesmo valor, inclusive podendo se zangar caso não sentissem essa reciprocidade. "Trata-se, no fundo, de misturas. Misturam-se as almas nas coisas, misturam-se as coisas nas almas. Misturam-se as vidas, e assim as pessoas e as coisas misturadas saem cada qual de sua esfera e se misturam: o que é precisamente o contrato e a troca" (Mauss, 2003, p. 212).

Porém, apesar de Mauss se debruçar mais intensamente sobre essas práticas agonísticas, Caillé (1998) nos indica por um caminho de pensamento que leve em conta as pluralidades de formas de partilha que podem ser vistas como dádivas ${ }^{5}$, sem nos obrigarmos a encaixar a rivalidade no centro das discussões; e, principalmente, que ao olharmos para as dádivas de diferentes sociedades e diferentes tempos não tenhamos a pretensão de localizar uma "essência eterna, invariável".

Às sociedades que praticam unicamente a dádiva-partilha pacífica opõem-se aquelas que colocam esta última sob a égide da dádiva agonística; às que pri-

5 “(...) dádiva - palavra que, lembramos, só é utilizada aqui para resumir aquilo que Mauss designava com mais justeza como a tripla obrigação de dar, receber e retribuir — (...)“(Caillé, 1998, p. 27). 
vilegiam a dádiva entre vivos, quer seja de partilha ou de desafio, opõem-se as que subsumem essa dádiva horizontal entre pares a uma dádiva aos mortos que poderíamos qualificar de transversal, ou a uma oblação às divindades, que poderíamos chamar de vertical (Caillé, 1998, p. 27).

Mauss (2003) observa outras sociedades em que a dádiva se faz presente, mas nas quais as razões para a terceira etapa, do retribuir, possuem uma extensão diferente daquelas analisadas anteriormente; neste artigo, me aterei a recordar as reflexões sobre o direito hindu clássico. Como aponta o autor, essa descrição da dádiva só está presente efetivamente entre os brâmanes; para eles, aquilo que é dado não só produz recompensas nesse mundo, como no próximo. Uma característica interessante é a perspectiva de que aquilo que se dá não é perdido, se reproduz, constitui para quem está dando algo idêntico; no próximo mundo, a mesma coisa reaparece aumentada. Tudo o que se dá é personificado e participante da dádiva, é tido como ser vivo com o qual se dialoga e que deseja ser dado, por exemplo, "é da natureza do alimento ser partilhado; não dividi-lo com outrem é "matar sua essência”, é destruí-lo para si e para os outros" (Mauss, 2003, p. 282); os brâmanes têm a concepção de que a riqueza é produzida para ser dada e se não existissem outros brâmanes para recebê-las não teriam sentido.

Mais próximo ao que foi observado na Polinésia e Melanésia, não existe tão fortemente marcado para os brâmanes as delimitações entre posses e quem as possui, aquilo que se dá é constituído por aquele que o deu, e o vínculo estabelecido pela dádiva entre quem recebe e quem doa é extremamente forte; "a própria coisa dada forma um vínculo bilateral e irrevogável, sobretudo quando é uma dádiva de alimento" (Mauss, 2003, p. 286).

Para não nos fecharmos apenas nos sentidos oferecidos por Mauss, podemos seguir a reflexão de Steiner (2016) que, ao pensar na solidariedade que é enfatizada pela reflexão maussiana, aponta para os estudos de Maunier, que contemporaneamente ao primeiro autor, elabora estudos sobre a dádiva. E, se por um lado, aceita a tríplice obrigação proposta, por outro, rejeita a ideia de um espírito mágico como o hau, que faria com que o que foi dado retornasse ao doador e atribui a retribuição à uma imposição moral, em que aquele que recebeu um bem, sente-se impelido a retribuir, já que são acionados sentidos de honra e constantemente em frente ao grupo, ao qual as expectativas ele deve atender. 


\section{A Dádiva do Torrent}

Apesar da análise de Mauss se concentrar em sociedades e tempos diferentes dos quais vivemos, ainda hoje existem traços de livre circulação de bens materiais e simbólicos díspares ao modelo do mercado e, inclusive em sociedades nas quais o capitalismo está avançado, ainda podemos encontrar a dádiva (Currah, 2007). E é através da atenção às práticas de download por torrent que se insere a investigação dessas dádivas contemporâneas.

\section{SOBRE O TORRENT}

Até a possibilidade de compartilhamento peer-to-peer ( $\mathrm{p} 2 \mathrm{p})$ ser desenvolvida e até hoje, o comum na internet tem sido o modelo servidor-cliente, isto é, um site fica hospedado em um servidor específico em algum lugar do mundo e apresenta as informações quando solicitado pelo usuário; ao fazer um download, o servidor envia o arquivo diretamente para o dispositivo que o demandou, e assim se repete com cada novo usuário/dispositivo. Com o modelo peer-to-peer, cada dispositivo torna-se um servidor, ao invés de apenas conseguir baixar arquivos, pode-se enviá-los a outros dispositivos, já não existe mais um servidor central. A tecnologia de compartilhamento de arquivos peer-to-peer não é utilizada apenas em casos de pirataria, mas essa pode ter sido a motivação de seu desenvolvimento, uma vez que é muito mais simples localizar um servidor central e tirá-lo da rede do que diversos espalhados, possivelmente, pelo mundo todo. Além disso, como as trocas não acontecem de forma bilateral, o deslocamento do arquivo vem de diversos servidores ao mesmo tempo, aumentando a velocidade do download 6 .

Ao baixar um arquivo de torrent e rodá-lo em um programa apropriado, o conteúdo do arquivo é, na verdade, diversos mapas ou guias de servidores diferentes dos quais o arquivo poderá ser baixado (Frostgård, 2012). Dessa forma, os arquivos são recebidos e enviados de maneira rizomática, não mais dual, em processos no qual se pode enviar e receber arquivos ao mesmo tempo para e de muitas pessoas ao mesmo tempo (Giesler, 2003).

Andrew Currah (2007) apresenta a perspectiva de que a internet foi desenvolvida a partir de uma mesma lógica socio-institucional da academia, o qual ele concebe como uma economia de dádiva ${ }^{7}$, uma vez que há muito tempo se oferece resultados

6 Extraído de https://www.makeuseof.com/tag/p2p-peer-peer-file-sharing-works/

7 "Gift economy", no original. 
de pesquisa de forma gratuita, estimulando novas pesquisas e descobertas científicas. E, continua, com o passar do tempo, os desenvolvimentos tecnológicos possibilitaram a redução dos custos e da complexidade na participação das pessoas com o meio, permitindo que cada vez mais pessoas possam trocar informações umas com as outras.

Apesar da história da internet ter sido marcada por diversos conflitos, controvérsias e lutas por autoridade e poder, com uma presença militar muito acentuada em seu desenvolvimento, e com diversas reconfigurações e reapropriações em suas décadas de desenvolvimento, o apontamento de Currah traz uma potência de sentido interessante se a explorarmos. Tanto o computador como a internet fizeram parte da elaboração de diferentes práticas relacionadas ao trabalho imaterial, não em si próprios, mas explicitamente a partir do compartilhamento de arquivos, que estimularam novas possibilidades de organização e relação social com os conteúdos de informação e culturais (Caraway, 2012). Além disso, a possibilidade da manipulação de arquivos digitais, como a "tradução" de arquivos musicais para o formato mp3, também exerceu forte influência na pirataria, pelas facilidades de armazenamento, deslocamento e compartilhamento, e pela reconfiguração dos empecilhos materiais na etapa de realizar uma cópia (Barros, et al., 2010). Essa outra relação de materialidade com o que é trocado é um grande ponto de cisão com as reflexões tradicionais acerca da dádiva.

Apesar dessas reconfigurações, mais uma vez precisamos posicionar de que a internet não é um admirável mundo novo, descolado da realidade mundana, mas existe dentro do sistema capitalista; e tratando de downloads e compartilhamentos de arquivos na internet essa reflexão é fundamental, porque apesar de nem sempre operar através das lógicas capitalistas, está sempre em relação direta, como o exemplo dos processos por direitos autorais explicitam (Frostgård, 2012).

A internet permitiu assim uma forma de dádiva prescrita sobre os termos digitais, na qual comunidades de indivíduos constantemente estão produzindo, apropriando e compartilhando uma quantidade incalculável de informações de maneira não necessariamente comercial. E, dessa forma, está inserida nessas relações online uma gama de relações de dádiva em diferentes formas que continuam se reconfigurando, principalmente se comparado aos estudos que até então demonstravam a dádiva organizada pela materialidade não virtual dos objetos e facilmente localizável geograficamente. A estrutura não centralizada da internet permite uma integração temporal e geográfica de informações e recursos entre diferentes pessoas, muitas vezes anô- 
nimas, através da rede. "Esses recursos não são apenas informativos e digitais (...), mas também infraestruturais e físicos (por exemplo, espaço livre em disco rígido, potência de processamento de computadores ou largura de banda de comunicações)" (Currah, 2007, p. 469).

Um dos modelos apresentados por Currah é o de código aberto; nesses casos, o código é livre, permitindo que qualquer pessoa (com conhecimento de programação) possa explorá-lo e desenvolvê-lo; e que essas novas transformações estejam disponibilizadas para futuros participantes. Não há donos únicos do projeto, ele se torna de todos e pela permissão desse contato, aperfeiçoa-se de maneira contínua e, possivelmente, rápida (Apgaua, 2004).

As mudanças advindas das práticas da internet são culturais e transformam também a percepção do mundo; diversas pesquisas, quantitativas e qualitativas sugerem que jovens, que cresceram em meios de fácil/rápido acesso à internet e dispositivos relacionados, tendem a significar a informação como algo maleável e que deve ser um recurso compartilhado entre pessoas (não apenas centralizado), além de estar aberto para modificações (Barros et al., 2010; Currah, 2007; Frostgård, 2012; Giesler \& Pohlmann, 2003; Giesler, 2006).

Uma modalidade de dádiva analisada por Currah (2007) é aquela que diz respeito diretamente às práticas de torrent, nas quais existem espaços que permitem o compartilhamento peer-to-peer. Um dos principais exemplos dessa concepção peer-to-peer vem através do Napster (objeto recorrente de pesquisas sobre o tema p2p), um serviço no qual os usuários poderiam compartilhar músicas (principalmente no formato $m p 3$ ) e fazer o download dos arquivos diretamente dos computadores de outros usuários, já que os computadores funcionam tanto como servidores quanto clientes. O caso do Napster ficou famoso, pois alguns de seus principais servidores eram locados em lugares conhecidos publicamente e, então, seus operadores não conseguiram manterem-se anônimos, tornando-se alvos de um processo judicial que culminou no fim do serviço em 2001; hoje, apesar de sua origem, ele foi transformado num sistema de streaming que vende músicas online.

Desde então, diversos serviços que oferecem a conexão peer-to-peer foram criados e desenvolveram uma abordagem descentralizada para o compartilhamento, na qual não é necessária uma coordenação central (Barros et al., 2010), além de que se expandiram os tipos de arquivos disponibilizados e, hoje, incluem vídeos, softwares e, praticamente, todo tipo de documento (Currah, 2007). Uma das grandes inovações veio com a possibilidade do que Currah coloca como "swarming download", nos 
quais arquivos grandes podem ser repartidos em pequenas partes e assim podem ser baixados a partir de fontes diferentes ao mesmo tempo, que é exatamente o caso do download por torrent. "Atualmente, as redes $\mathrm{p} 2 \mathrm{p}$ fornecem a maneira mais econômica de armazenar e distribuir informações para redes de usuários geograficamente dispersas (especialmente para conteúdo intensivo de dados, como filmes, programas de televisão e software)" (Currah, 2007, p. 480).

Uma questão importante para diversos autores ao pensar a dádiva na internet é de que existe uma característica de participação assimétrica, ou seja, a de que alguns usuários costumam "se aproveitar" daquilo que é alimentado por um "grupo relativamente pequeno de entusiastas"; e que a anonimidade natural dessas relações virtuais permitiria que se pegasse mais do que se dá. Por outro lado, Currah (2007) pontua otimista, isso pode ser aliviado pelo fato de que as informações na internet são copiadas e distribuídas "gratuitamente"8 e que, numa comparação para o autor as vantagens da colaboração e partilha superariam a perda dos usuários que não se envolvem.

Por outro lado, quando pensamos no torrent, que prevê o "swarming download", perceberemos que existe uma relação de obrigação/liberdade entre os usuários e, no qual pode ser um grande problema a não participação na lógica da dádiva. Isso porque a principal característica desse modo de download permite que um usuário baixe os pedaços de arquivos de diversos outros usuários na rede, tornando mais rápida a transação online; quanto mais pessoas estiverem compartilhando os fragmentos de arquivo, mais fácil é seu acesso; e assim, ao mesmo tempo, confundem-se aqueles que dão e aqueles que recebem (Giesler, 2003).

Desde o início, um dos principais objetivos dessa modalidade foi a busca por colaborações e nos próprios programas usados para o download, o usuário acompanha seu download ao mesmo tempo em que acompanha seus arquivos serem levados para outros usuários; a não participação na dádiva torna-se um problema para todas as pessoas envolvidas com o arquivo, pois se alguém apenas baixa um arquivo e não o mantém na rede para permitir que outros usuários possam também recebê-lo, a velocidade de download desse arquivo diminui, assim como, muitas vezes, torna-se mais difícil encontrá-lo, podendo o arquivo, inclusive, ser extinto, uma vez que ninguém mais se torne "fornecedor" deste.

8 Aspas importantes, pois apesar do compartilhamento de informações ser gratuito na internet, ainda está ligada a relações materiais, como energia elétrica, por exemplo. 


\section{A Dádiva do Torrent}

\section{HÁ DÁDIVA NO TORRENT?}

Tendo concebido que é a dádiva o que está criando conexões entre pessoas diferentes, colocando-as em contato a partir de uma mesma cadeia de obrigações, desafios e benefícios, nenhuma das características isoladas será capaz de interpretá-la completamente, "já que não é senão uma aposta sempre única que liga as pessoas, ligando simultaneamente, e de uma maneira sempre nova, o interesse, o prazer, a obrigação e a doação" (Caillé, 1998, p. 30).

Uma primeira associação é a ideia da dádiva em relação ao mercado, o torrent chama atenção enquanto dádiva por não operar no modelo de mercado econômico atual. Como coloca Currah (2007), os usuários estão permitindo acesso e compartilhando informações, em geral, por razões não econômicas; - em alguns casos, percebeu uma movimentação pautada pelo desenvolvimento de capital social e cultural em suas diversas formas, assim como Giesler (2006) e Frostgård (2012) -; além de que essas práticas se opõem diretamente às fontes de lucro de muitas corporações das quais boa parte dos conteúdos é proveniente.

Agora, pelo outro lado, é necessário também colocar que apesar das práticas de download por torrent estarem relacionadas às instituições econômicas capitalistas, não significa que estão imersas na lógica mercantil; nesse caso, o que estará sendo tomado como mercado pode estar considerando apenas uma de suas características, a regra da equivalência, não considerando os contextos e vínculos (Apgaua, 2004). Além disso, Caraway (2012) indica como a própria persistência desse modelo de compartilhamento de arquivos frente à uma ação legal e policial em larga escala antipirataria demonstra impotências do capitalismo em moldar o destino dessa prática. "A dádiva escapa ao modelo mercantil, por suas características paradoxais, como: gratuidade e retorno, interesse e desinteresse, liberdade e obrigação, desigualdade nas trocas, prazer em dar, espontaneidade, fortalecimento do vínculo, etc." (Apgaua, 2004, p. 230).

Currah (2007) percebe que aqueles que participam de relações de dádiva na internet, muitas vezes também estão ligados por uma duradoura teia moral de comprometimentos e obrigações e que, através das reciprocidades promove uma coesão descentralizada e, eventualmente, constrói uma rede de recursos comuns e valores compartilhados; muitas vezes em grupos fechados de compartilhamento por torrent, a elaboração dessa "ética" vem através de regras (e às vezes sanções) e não de maneira espontânea (Giesler; Pohlmann, 2003). Então, por um lado, podem ser observados 
valores semelhantes e práticas comuns entre usuários que, inclusive, falam sobre um senso de partilha, por outro lado, muitas vezes também existe coerção para que certas aplicações sejam realizadas. Dito isso, é necessário reiterar de que não podemos conceber as relações entre usuários de torrent como um meio coeso; são múltiplas as práticas, as motivações e os usos que são aplicados nessa experiência, levando sempre em conta as plataformas e espaços virtuais através dos quais acontecem os contatos com o torrent (Frostgård, 2012).

Muitas pesquisas etnográficas já foram realizadas com o objetivo de, entre outras coisas, investigar as motivações das pessoas que compartilham arquivos por torrent e as respostas variam em direções. Algumas pessoas trazem à tona o prazer em sentir-se parte de uma comunidade e poder ajudar pessoas a acessar diferentes bens culturais (Caraway, 2012); outros dizem que se envolvem com as práticas pelo prazer de descobrir coisas novas (Caraway, 2012); muitos configuram a relação com o compartilhamento por torrent como uma forma de se libertar ou se colocar contra a forma como a indústria distribui seus bens culturais (Barros et al., 2010; Frostgård, 2012; Giesler \& Pohlmann, 2003); alguns, como citado acima, posicionam sua motivação na acumulação de capital simbólico, que se dá principalmente a partir de grupos fechados em que se obtém certo status uma vez que disponibilize muitos arquivos (Frostgård, 2012); ainda alguns usuários dizem que seu objetivo na utilização do torrent é desenvolver grandes arquivos digitais, às vezes separado por tema (como mangás), às vezes por tipo de arquivo (como o mp3, para música) (Frostgård, 2012).

É imprescindível marcar as pesquisas que já se debruçaram sobre as motivações daqueles que compartilham arquivos por torrent, pois um grande ponto de cisão acadêmica na contextualização da dádiva contemporaneamente, e no meio da internet, é a discussão se existe solidariedade ou altruísmo envolvido nessa experiência. Steiner (2016) retoma como a reflexão de Bourdieu em torno das trocas simbólicas foi desenvolvida também em diálogo com a elaboração da concepção de dádiva, que de um lado marcada por Mauss (assim como Comte e Caillé, de acordo com o autor) implicava no interesse desinteressado ou no altruísmo e abnegação em prol de outro modelo econômico que não de mercado; e de outro, que além de Bourdieu, ele exemplifica a partir de Maunier, vão enxergar nesse "desinteresse" outras fontes de interesse que estruturam diferentes tipos de capital.

Essa dicotomia é mais uma que precisa ser rompida, saber as motivações das pessoas em relação ao uso do torrent, principalmente no momento contemporâneo em que a lógica capitalista (e de interesse) é hegemônica e definida acaba tornando-se 
não tão relevante quanto perceber as pessoas fazendo parte do ritual triplo, trocando bens de forma não mercantil e entre si de maneira rizomática constantemente. Cada pessoa terá uma percepção do assunto e terá uma motivação, não completamente subjetiva e única, mas diferentes motivações aparecem, assim como nos grupos estudados por Mauss (2003) que, apesar de participarem de um sistema de prestações pela dádiva, o configuram de diferentes formas, com diferentes valores e interesses.

As relações são complexas mesmo quando elencamos certas motivações como pontos de partidas, como por exemplo, uma postura contra-hegemônica em resposta ao modelo de distribuição de bens culturais e simbólicos; conjunturalmente, ao pensarmos as dádivas na internet é necessário frisar que elas permitem uma alternativa de trocas e experimentações sociais, que não estão independentes do mercado capitalista, mas ao mesmo tempo o disputa, complementa, sustenta e amortece (Currah, 2007). Tanto que, ao pensarmos na modalidade do código livre, ele não corresponde diretamente à gratuidade do software (Apgaua, 2004); na análise da trajetória do Linux, percebe que em torno desse sistema operacional constitui-se “(...) um espaço de sociabilidade em que passam a participar, além dos geeks, as empresas/suits, os órgãos governamentais e os usuários comuns" (Apgaua, 2004, p. 232).

Outra característica das dádivas que deve ser observado em relação às práticas de download por torrent é a questão das coletividades que, para Mauss (2003), são as participantes das trocas. Então, entramos em outro ponto complexo nos debates acadêmicos acerca da dádiva nos compartilhamentos peer-to-peer, a ideia de "comunidade". Por um lado, podemos pensar que quem participa dessas práticas são indivíduos, ainda mais caracterizados pela noção de peer-to-peer, logo, que seria uma forma de dádiva que pressupõe sujeitos. Por outro lado, Apgaua (2004) reflete sobre a afirmação de Eric Raymond no qual coloca que a cultura hacker é uma cultura da dádiva, o que pode ser entendido por uma ética hacker que pressupõe o compartilhamento de informações. Giesler e Pohlmann (2003) acionam o sentido de comunidade ao trabalhar o modo rizomático se dá no compartilhamento via torrent, a reciprocidade não se dá diretamente a um grupo ou individuo, mas em resposta ao grupo como um todo.

Apesar desses entendimentos, Caraway (2012) elabora em sua pesquisa uma árdua argumentação pautada nos relatos de pessoas entrevistadas em que, em diversos momentos, é colocado o fato de não haver uma comunidade, ou algo que seria entendido como "a" comunidade. São diversas relações entre indivíduos, entre grupos formais ou ocasionais, entre indivíduos e grupos que desenvolvem a malha de agrupamentos possíveis a partir do torrent. "Na Teoria Ator-Rede, o social não pode ser a 
cola que mantém a rede unida. No lugar, essa comunidade, ou senso de comunidade, ao qual os membros se referem é um produto da complexa interação entre diferentes actantes" (Frostgård, 2012, p. 44). Frostgård é completamente assertivo ao se opor a uma ideia de "comunidade de torrent" já que as relações que se estabelecem entre pessoas, coletivos e coletividades fogem das explicações mais tradicionais do conceito; ele rompe com a ideia de Giesler e Pohlmann (2003) em que a grande catalisadora da dádiva seria a "comunidade" e passa a valorizar os actantes.

E não se encerram facilmente as possibilidades de comunidades, Currah (2007) chega a falar sobre os grupos na internet que fornecem legendas para os conteúdos audiovisuais distribuídos de forma pirata na internet; e isso existe também para os torrents, no fim, não é apenas o uso individual das pessoas que move os bens pela dádiva na internet, mas muito provem de associações entre pessoas para juntas conseguirem não só converter os arquivos piratas para disponibilizar por torrent, mas nas construções de sites, fóruns, bibliotecas os quais fazem parte dessa cultura de download e, também, nas associações para lidar com as questões jurídicas que recorrentemente tiram arquivos ou sites de disponibilização de torrents do ar. Nesse encontro entre as coletividades que sociabilizam também através do torrent e as práticas anti-hegemônicas (em relação à circulação de bens no capitalismo contemporâneo), pode-se encontrar um aspecto cultural e simbólico importante ao pensamento sobre o consumo (Kopytoff, 2008).

Embora muitas características e práticas se aproximem dos modelos de dádiva tradicional em certos aspectos, é importante falar sobre os distanciamentos intrínsecos à dádiva contemporânea no compartilhamento de arquivos digitais.

Giesler e Pohlmann (2003) apontam para uma distensão nas compreensões da dádiva para a reflexão no ambiente virtual e apresentam quatro pontos de distanciamento com o que foi observado pelos antropólogos clássicos: o primeiro seria o fato de o bem "dado" ser uma cópia exata que se situa no servidor do doador; o segundo, geralmente o doador é o receptor e o receptor é o doador ao mesmo tempo, mas não necessariamente numa relação um com o outro; terceiro, é quem recebe que inicia a troca pela dádiva e não quem doa; e em quarto, os participantes da dádiva são anônimos e não necessariamente existe uma reciprocidade direta. Inclusive, uma das respostas dos entrevistados de Caraway (2012) questionou a ilegalidade no compartilhamento desses bens, já que o que é categorizado como roubo pela legislação dos Estados Unidos não corresponde ao que ocorre com o uso do torrent. Diferentemente da compra de um cd pirata físico, pelas condições materiais e simbólicas da troca 


\section{A Dádiva do Torrent}

por torrent, aquele que compartilha não está ganhando nada com a transação, não há dinheiro envolvido.

Os arquivos ou informações compartilhadas apresentam outro ponto importante na reflexão em relação à dádiva; uma vez que são trocadas ao serem acumuladas, é necessário manter o arquivo de torrent no seu computador caso seu objetivo seja compartilhar com outra pessoa, porém, sendo um bem virtual, esse acúmulo também é virtual. Nesse aspecto, diferente da forma apresentada por Mauss, não se cinde tão fortemente pessoa e coisa, como apresentado por Kopytoff (2008), já que estão imbricadas, no mínimo, pela circulação. Além disso, é curiosa a forma que virtualmente se lida com o dar e receber, já que ao se dar, na verdade se replica; ao disponibilizar seu computador como uma fonte de arquivo (participando do dar e retribuir), a pessoa não "perde" o que acabou de oferecer, mas esse arquivo será replicado no computador de quem recebe; a dádiva tradicional preveria um tipo de sacrifício que não ocorre no compartilhamento de arquivos via torrent (Giesler, 2006).

Isso causa uma curiosa analogia com o que foi observado por Mauss entre os brâmanes: "Aqui, ela engendra automaticamente para o doador uma coisa idêntica a si mesma: ela não é perdida, ela se reproduz" (Mauss, 2003, p. 280).

Isso significa que as informações podem ser compartilhadas com redes geograficamente extensas de usuários sem que elas saiam da posse do proprietário. Como tal, o conteúdo digital (por exemplo, arquivos, hiperlinks, código de software) é uma classe incomum de dádiva que pode ser doada e, finalmente, retida. A Internet, consequentemente, incorpora uma "economia da abundância", porque as dádivas digitais proliferam (e não se esgotam) e permanecem em circulação9 (Currah, 2007, p. 476).

Apesar de vivermos em um mundo em que a força do capitalismo é hegemônica, ainda preservamos traços das trocas pela dádiva e também concebemos muitas vezes as coisas por seu valor sentimental, não apenas utilitário (Mauss, 2003); existem ainda sociabilidades que se mantém atreladas pelo duplo paradoxo, como aquelas que envolvem o download por torrent, entre liberdade e obrigação, desinteresse e interesse.

9 Tradução nossa. 


\section{CONSIDERAÇÕES FINAIS}

Que adotemos então como princípio de nossa vida o que sempre foi um princípio e sempre o será: sair de si, dar, de maneira livre e obrigatória; não há risco de nos enganarmos. Um belo provérbio maori diz: "Dá tanto quanto tomas, tudo estará muito bem" (Mauss, 2003, p. 301)

Não foi o objetivo desse trabalho apresentar hipóteses que justifiquem quais as motivações da retribuição por parte dos usuários que fazem download por torrent; podemos vislumbrar os diferentes motivos das diferentes culturas apresentadas para entender que, contemporaneamente, podem (ou não) ser outros ideais que movem essa reciprocidade, inclusive razões egoístas (como a necessidade que se tem dos outros para se obter os bens); mas é exatamente por isso, também, que se torna inútil essa procura pelas motivação, uma vez que nas relações entre os peers, a partir do torrent, a dádiva é pressuposto, pois está imbricada a tríplice dar, receber e retribuir. Assim que se faz o download do arquivo no computador por um programa de torrent, ele automaticamente começa a se disponibilizar para outros usuários; pode-se interromper essa transação ao deletá-lo, mas sem essa interrupção, em algum momento, há participação no ato de retribuir, assim como o dar e receber.

Um ponto importante, razão de muitos conflitos ligados ao interesse pela motivação dos usuários, é a ideia de solidariedade; precisamos mesmo buscar uma motivação altruisticamente pura, precisamos manter a ideia de dádiva ligada à ideia de solidariedade? Ou então precisamos jogar para o outro lado da dicotomia e pensar que não existe solidariedade alguma e apenas egoísmo? Não seriam as relações e usos com as práticas de download por torrent uma forma de reconfigurar nossos olhares para as ideias de compartilhamento e trocas, modificando aos poucos as subjetividades e discursos hegemônicos no mundo?

Assim, o compartilhamento de arquivos não é visto como o produto simples do desenvolvimento tecnológico ou dos imperativos do mercado, mas como um sistema social que depende de significados e materiais compartilhados para a coordenação e reprodução de atividades de compartilhamento de arquivos. Também de acordo com Giddens, considero que compartilhadores de arquivos 


\section{A Dádiva do Torrent}

sejam atores sociais conhecedores capazes de promover nossa compreensão das condições sob as quais suas atividades ocorrem (Caraway, 2012, p. 566, tradução nossa).

Outro ponto intrigante e debatido extensivamente em diversas bibliografias sobre o assunto é a noção de comunidade ou coletividades que participam das trocas pela dádiva a partir dos torrents. Para muitos, a noção de comunidade é necessária para a compreensão da dádiva, mas como Frostgård (2012) indica, talvez o caminho seja enxergar e pesquisar os actantes presentes nessa relação; caso o contrário, a ideia de comunhão segue a ânsia pela motivação. Devemos parar de tentar separar o mundo entre o bem e o mal e pautar nossas análises a partir do que reconhecemos como altruísmo ou egoísmo puro; nada no mundo é tão simples.

Por fim, como coloca Currah (2007), o meio da internet possibilita, e com isso ele mesmo ganha, a partir das diversas partilhas que ocorrem entre milhões de pessoas estranhas umas às outras. Não só nesse ponto, mas a dádiva nesse espaço virtual oferece um modo de produção e distribuição de trabalhos criativos numa forma de compartilhamento em larga escala. Para esse autor, que se preocupa em manter a ordem econômica hegemônica, aparecem alguns problemas em relação à dádiva e o mercado contemporâneo. Pois, por um lado, um controle excessivo por parte das corporações produtoras de conteúdo institucionalizado (como conglomerados de mídia) implica a não circulação e menor reconfiguração desses conteúdos entre os usuários; por outro lado, ele acredita que, sem uma legislação que atue no sentido de um retorno de receita para esses produtores isso causaria que esses conteúdos, que preenchem boa parte da internet, desaparecessem.

Provavelmente, a dádiva só é "paradoxal" ou "estranha" quando vista pelas lentes do mercado, sem esquecer que estamos em um contexto em que o pensamento mercantil parece reinar e ser a chave de explicação por excelência. Fora do sistema mercantil de interpretação, ela deixa de ser a "coisa estranha". Para compreendê-la, é preciso sair deste círculo do pensamento mercantil e buscar outras abordagens que não "estranhem" a possibilidade do paradoxo, da contradição. Sem esquecer que o paradoxo e a contradição só existem enquanto tal, na medida em que são criados e sustentados pela razão moderna (Apgaua, 2004, p. 231). 
Deixo essa reflexão como uma provocação, mas também é importante apontar que esse paradoxo só existe dentro de uma concepção de mundo que prevê em sua base o modelo econômico capitalista; outros modos de produção e circulação de bens poderiam, inclusive, surgir a partir das práticas de trocas pela dádiva na internet.

Ademais, é necessário nos posicionarmos, como Mauss (2003) coloca, a favor da dádiva e dar atenção a esses modos de trocas e sociabilidades, pois podem indicar um caminho social, cultural, econômico diferente do que conhecemos, principalmente nessas primeiras décadas do uso humano proliferado da internet; já existem diversas empresas e serviços entendendo como desmontar as lógicas da dádiva no sentido das lógicas do mercado contemporâneo e, se não tomarmos consciência, quem principalmente influenciará o rumo do mundo serão essas instituições.

\section{REFERENCIAS}

Apgaua, R. (2004). O linux e a perspectiva da dádiva. Horizontes Antropológicos, v. $10,221-240$.

Barros, D. F., Sauerbronn, J. F., Costa, A. M., Darbilly, L. V., \& Ayrosa, E. A. (2010). Download, pirataria e resistência: uma investigação sobre o consumidor de música digital. Comunicação, Mídia e Consumo, v. 7, n. 18, 125-151.

Caillé, A. (1998). Nem holismo nem individualismo metodológicos: Marcel Mauss e o paradigma da dádiva. Revista Brasileira de Ciências Sociais, v. 13, 5-38.

Campbell, C. (2006). Eu compro, logo sei que existo: as bases metafísicas do consumo moderno. In L. Barbosa \& C. Campbell. Cultura, Consumo e Identidade (pp. 4764). Rio de Janeiro: Editora FGV.

Caraway, B. R. (2012). Survey of file-sharing culture. International Journal of Communication, v. 6. Disponível em https:/ijoc.org/index.php/ijoc/article/ view/1216/720

Currah, A. (2007). Managing creativity: the tensions between commodities and gifts in a digital networked environment. Economy and Society, v. 36, 467-494. 
Frostgård, C. (2012). There is no "I" in torrent: collective effort and the collected self in peer-to-peer file-sharing networks. $64 \mathrm{f}$. Dissertação (Mestrado) - Division of ALM, Lunds Universitet. Disponivel em https://lup.lub.lu.se/student-papers/ search/publication/2701498

Giesler, M. (2006). Consumer Gift Systems: Figure 1. Journal of Consumer Research, 33(2), 283-290. doi:10.1086/506309

Giesler, M., \& Pohlmann, M. (2003). The anthropology of file sharing: Consuming Napster as a gift. Advances in Consumer Research, 30, 273-279. (IMAGENS)

Jeffman, T. (2017). Booktubers: Performances e conversações em torno do livro e da leitura na comunidade booktube. 395 f. Tese (Doutorado) - Programa de Pós-graduação em Ciência da Comunicação, Universidade do Vale do Rio dos Sinos.

Kopytoff, I. (2008). A biografia cultural das coisas: a mercantilização como processo. In A. Appadurai (Org.), A Vida Social das Coisas. Niterói: Editora da Universidade Federal Fluminense.

Mauss, M. (2003). Sociologia e antropologia. São Paulo: Cosac Naify.

Miller, D. (2007). Consumo como cultura material. Horizontes Antropológicos, v. 13, 33-63.

Sabourin, E. (2008). Marcel Mauss: Da dádiva à questão da reciprocidade. Revista Brasileira de Ciências Sociais, v. 23, 131-138.

Steiner, P. (2016). Altruísmo, dons e trocas simbólicas: abordagens sociológicas da troca. São Paulo: Cultura acadêmica. 